\title{
Effect of Physico-Chemical Properties on Soil Enzyme Acid Phosphatase Activity of Some Soils in Vegetable Growing Soils of Ranga Reddy District of Telangana State, India
}

\author{
J. Aruna Kumari ${ }^{*}$, P.C. Rao ${ }^{1}$, G. Padmaja ${ }^{2}$, M. Madhavi ${ }^{3}$ \\ ${ }^{1}$ Department of Biochemistry, College of Agriculture, Rajendranagar, PJTSAU, India \\ ${ }^{2}$ Agricultural College, Jagital \\ ${ }^{3}$ ACRPP, Weed control, Rajendranagar, India \\ *Corresponding author
}

\begin{tabular}{|c|c|}
\hline & A B S T R A C T \\
\hline $\begin{array}{l}\text { Physico-chemical, } \\
\text { Acid phosphatase, } \\
\text { Organic carbon, } \\
\text { Electrical } \\
\text { conductivity. }\end{array}$ & \multirow{3}{*}{$\begin{array}{l}\text { Physico- chemical properties of soil have profound influence on soil enzyme acid } \\
\text { phosphatases activity. To study the distribution of soil enzyme acid phosphatase and } \\
\text { influence of physico- chemical properties on soil enzyme acid phosphatases activity forty } \\
\text { soil samples were collected from different villages of Ranga Reddy district of Telangana } \\
\text { state. These samples were analysed for the physicochemical properties like pH, EC, } \\
\text { available nutrients, texture and organic carbon and soil enzyme activity was assayed. Acid } \\
\text { phosphatase activities of the soil expressed as } \mu \mathrm{g} \text { of } 4 \text {-nitrophenol released } \mathrm{g}^{-1} \mathrm{soil}^{-1} \\
\text { ranged from } 18.93 \text { to } 51.2 \text { with an average value of } 31.79 \text {. The pH ranged from } 5.7 \text { to } 8.9 \text {, } \\
\text { electrical conductivity from } 0.1 \text { to } 1.23 \mathrm{dSm}^{-1} \text { and organic carbon from } 0.13 \text { to } 1.48 \% \text {. } \\
\text { The available Nitrogen varied from } 201.5 \text { to } 472.5 \mathrm{~kg} \mathrm{ha}^{-1} \text {. The available } \mathrm{P}_{2} \mathrm{O}_{5} \text { status in the } \\
\text { soils varied from } 11.6 \text { to } 79.1 \mathrm{~kg} \mathrm{ha}^{-1} \text {. The range of available } \mathrm{K}_{2} \mathrm{O} \text { ranged from } 118 \text { to } 411 \\
\mathrm{~kg} \mathrm{ha}^{-1} \text {. Acid phosphatase significantly, positively correlated with organic carbon }(\mathrm{r}= \\
\left.0.735^{* *}\right) \text { and available } \mathrm{P}\left(\mathrm{r}=0.776^{* *}\right) \text {. Acid phosphatase activity did not show any } \\
\text { significant correlation either with silt, clay and } \mathrm{pH} \text {. }\end{array}$} \\
\hline Article Info & \\
\hline $\begin{array}{l}\text { Accepted: } \\
\text { 28 September } 2017 \\
\text { Available Online: } \\
10 \text { October } 2017\end{array}$ & \\
\hline
\end{tabular}

\section{Introduction}

Soil is important among all the components of terrestrial ecosystems and is a main source of production in agriculture. Since soil is a dynamic system there is a continuous reaction between soil minerals, organic matter and organisms. These reactions influences physiochemical and biological properties of soil. Soil phosphatases is one of enzyme which plays a major role in the mineralisation processes (dephosphorylation) of organic $\mathrm{P}$ substrates.

The most extensively studied group among the phosphatases in soils is the phosphomonesterases, acid phosphatase (EC
3.1.3.2). In agricultural soils phosphatase activity is affected by soil properties, crop plants and farming systems.

Enzymes catalyze all biochemical reactions and are an integral part of nutrient cycling in the soil. Soil enzymes are believed to be primarily of microbial origin but also originate from plants and animals (Tabatabai, 1994). They are usually associated with viable proliferating cells, but enzymes can be extracted from both living and dead cells (Tabatabai, 1994). Soil enzymes are considered to be indicative measures of soil fertility (Zahir et al., 2001). 
Since enzyme activity is linked with several ecosystem processes including soil formation, organic matter transformation and bioremediation activities, it is important to understand the different physico-chemical factors affecting the enzyme activities.

\section{Materials and Methods}

Forty soil samples were collected from different mandals of Ranga Reddy district of southern Telengana zone. These samples were air dried and passed through $2 \mathrm{~mm}$ sieve before use. These soils samples were analyzed for their different soil properties viz. physical, physico-chemical and chemical properties by using standard procedures (Jackson, 1973). Soil $\mathrm{pH}$-The $\mathrm{pH}$ of soil was determined in 1:2.5 soil- water ratio as described by Jackson (1973) using a digital combined glass electrode pH meter (model DI-707). Electrical Conductivity $\left(\mathrm{dSm}^{-1}\right)$-The EC was determined in 1:2.5 ratio of soil to water extract as detailed by Jackson (1973) using a digital conductivity bridge and expressed in $\mathrm{dSm}^{-1}$ (model DI - 909). Organic Carbon (\%) Organic carbon in soil was estimated by Walkley and Black (1934) method and as described by Jackson (1973). It is expressed as percentage of organic carbon. Mechanical Analysis-Mechanical composition of soils was determined by Bouyoucos hydrometer method (Bouyoucos, 1962). The relative proportion of sand, silt and clay of soils were determined to describe their textural classes were carried out with the help of international triangle (Singh, 1980). Available Nitrogen (kg $\mathrm{ha}^{-1}$ ) -The available nitrogen was determined by Macrokjeldhal distillation method using alkaline potassium permanganate method as described by Subbaiah and Asija, (1956) and modified alkaline $\mathrm{KMnO}_{4}$ method by Sahrawat and Barford and expressed as $\mathrm{kg} \mathrm{ha}$ 1. Available Phosphorus ( $\left.\mathrm{kg} \mathrm{ha}{ }^{-1}\right)$-The available phosphorus was determined by Olsen's method (1954). The blue colour was developed by using L-ascorbic acid in this method. The intensity of blue colour developed was measured by using spectrophotometer at $420 \mathrm{~nm}$ and expressed as $\mathrm{kg} \mathrm{ha}^{-1}$. Available Potassium $\left(\mathrm{kg} \mathrm{ha}^{-1}\right)$-The available Potassium in soil was estimated by using neutral normal ammonium acetate extractant (Jackson, 1967) by using Elico flame photometer and expressed as $\mathrm{kg} \mathrm{ha}^{-1}$.

The procedure of Tabatabai and Bremner (1969) and Eivazi and Tabatabai (1977) were adopted for the assay of acid and alkaline phosphatases respectively. Modified Universal Buffer (MUB) Stock: The stock of MUB was prepared by mixing $12.1 \mathrm{~g}$ of Tris (hydroxymethyl) aminomethane (THAM), $11.6 \mathrm{~g}$ of maleic acid, $14 \mathrm{~g}$ of citric acid and $6.3 \mathrm{~g}$ of boric acid in $488 \mathrm{ml}$ of $1 \mathrm{~N}$ sodium hydroxide and the solution was diluted to 1 litre with distilled water. Modified Universal Buffer (pH 6.5): $200 \mathrm{ml}$ of MUB stock was transferred to 1 litre beaker and kept on a magnetic stirrer and the $\mathrm{pH}$ of the solution was adjusted to 6.5 with $0.1 \mathrm{~N} \mathrm{HCl}$ and volume was made up to 1 litre with distilled water. P-nitrophenyl phosphate solution $(0.025 \mathrm{M})$ : This was prepared by dissolving $0.420 \mathrm{~g}$ of disodium salt of p-nitrophenyl phosphate in $40 \mathrm{ml}$ of MUB pH 6.5 (for assay of acid phosphatase) and the solution was diluted to $50 \mathrm{ml}$ with MUB of the same $\mathrm{pH}$. The solution was wrapped with carbon paper and stored in a refrigerator. Calcium chloride $(0.5 \mathrm{M})$ : This was prepared by dissolving $73.5 \mathrm{~g}$ of $\mathrm{CaCl}_{2} \cdot 2 \mathrm{H}_{2} \mathrm{O}$ in distilled water and made up to 1 litre. Sodium hydroxide $(0.5 \mathrm{M})$ : $20 \mathrm{~g}$ of sodium hydroxide was dissolved in $700 \mathrm{ml}$ of distilled water and diluted to 1 litre with water.

Standard p-nitrophenol solution: Primary stock solution of $1000 \mu \mathrm{g} \mathrm{ml}{ }^{-1}$ of $\mathrm{p}$ nitrophenol was prepared by dissolving $1 \mathrm{~g}$ of p-nitrophenol in distilled water and made up to 1 litre. From this, secondary stock of 100 
$\mu \mathrm{g} \mathrm{ml}{ }^{-1}$ and $20 \mu \mathrm{g} \mathrm{ml} \mathrm{ml}^{-1}$ solutions were prepared. Working standards of $1,2,3,4,5$, $6,7,8,9$ and $10 \mu \mathrm{g} \mathrm{ml}^{-1}$ were prepared from $20 \mu \mathrm{g} \mathrm{ml}^{-1}$ stock and the absorbance of these standards were recorded at $420 \mathrm{~nm}$ in spectrophotometer. This was used for the standard curve. To $1 \mathrm{~g}$ of soil sample taken in glass tubes, $4 \mathrm{ml}$ of modified universal buffer $\mathrm{pH} 6.5$ was added followed by addition of 1 $\mathrm{ml}$ of 4-nitrophenyl phosphate solution.

The glass tubes were swirled for few seconds to mix the contents, stoppered and incubated for one hour at $37 \pm 0.5^{\circ} \mathrm{C}$ in BOD incubator. To these, $1 \mathrm{ml}$ of $0.5 \mathrm{M} \mathrm{CaCl} \mathrm{Ca}_{2}$ was added followed by addition of $4 \mathrm{ml}$ of $0.5 \mathrm{M} \mathrm{NaOH}$ to deactivate the enzyme and to extract the 4nitrophenol liberated. The glass tubes were swirled and the soil suspension was filtered through Whatman No. 42 filter paper. The absorbance of yellow color of 4-nitrophenol liberated due to hydrolysis of the substrate by phosphomonoesterases was measured at 420 nm. Controls were run simultaneously following the same procedure except adding 1 $\mathrm{ml}$ of 4-nitrophenyl phosphate after the addition of $1 \mathrm{ml}$ of $0.5 \mathrm{M} \mathrm{CaCl}_{2}$ and $4 \mathrm{ml}$ of $0.5 \mathrm{M} \mathrm{NaOH}$. Corrections were made for control / blank values.

Correlation study was carried out to find the relationship between soil properties and soil enzyme activities.

\section{Results and Discussion}

The results of the analysis of these initial soil samples varied in texture from clayey to sandy loam. The $\mathrm{pH}$ ranged from 5.7 to 8.9, electrical conductivity from 0.1 to $1.23 \mathrm{dSm}^{-1}$ and organic carbon from 0.13 to $1.48 \%$. The available $\mathrm{N}$ varied from 201.5 to $472.5 \mathrm{~kg}$ $\mathrm{ha}^{-1}$. The available $\mathrm{P}_{2} \mathrm{O}_{5}$ status in the soils varied from 11.6 to $79.1 \mathrm{~kg} \mathrm{ha}^{-1}$. The range of available $\mathrm{K}_{2} \mathrm{O}$ ranged from 118 to $411 \mathrm{~kg} \mathrm{ha}^{-1}$. These results showed that soil samples collected exhibited a wide variation in their properties. They are slight acidic to alkaline in reaction and non - saline in nature. Acid phosphatases activity ranged from $18.93 \mu \mathrm{g}$ of 4-nitrophenol released $\mathrm{g}^{-1}$ soil $\mathrm{h}^{-1}$ in sample 26 to $51.2 \mu \mathrm{g}$ of 4-nitrophenol released $\mathrm{g}^{-1}$ soil $\mathrm{h}^{-1}$ in sample 27. Acid phosphatase significantly, positively correlated with organic carbon $\left(\mathrm{r}=0.735^{* *}\right)$ and available $\mathrm{P}$ $\left(\mathrm{r}=0.776^{* *}\right)$. Acid Phosphatases activity did not show any significant correlation either with silt, clay and $\mathrm{pH}$. The higher correlation of phosphatase activity with organic carbon content could be due to the fact that the organic matter is the seat of microbial population and activity

These results on soil properties represented here are similar to the results obtained by Kalyani, (2011), Vandana, (2012) and Pavani, (2015). Vandana, (2012) also showed significant positive correlation of phosphatase with organic carbon and insignificant correlation with $\mathrm{pH}$ and clay. Sriramachandrasekhar et al., (1997). Gianfreda et al., (2005) found a significant positive correlation of urease and phosphatase with organic carbon content, available nitrogen and available phosphate. The relationship of phosphatase activity to soil organic phosphorous content has been the subject of several studies.

Khaziev and Burangulova (1965) recorded inverse relationships between organic phosphorous contents and soil nuclease, phytase, glyecrophosphatases and phosphatase activities. Nannipieri et al., (1973) observed significant positive correlation between phosphatase activity and organic matter content in soil. While Harrison, (1983) reported a significant positive relationship between phosphatase activity and organic carbon content in woodland soils. Speir, (1977) showed that phosphatase activity significantly correlated with organic carbon (Fig. 1). 
Fig.1 Soil enzyme activity in various samples

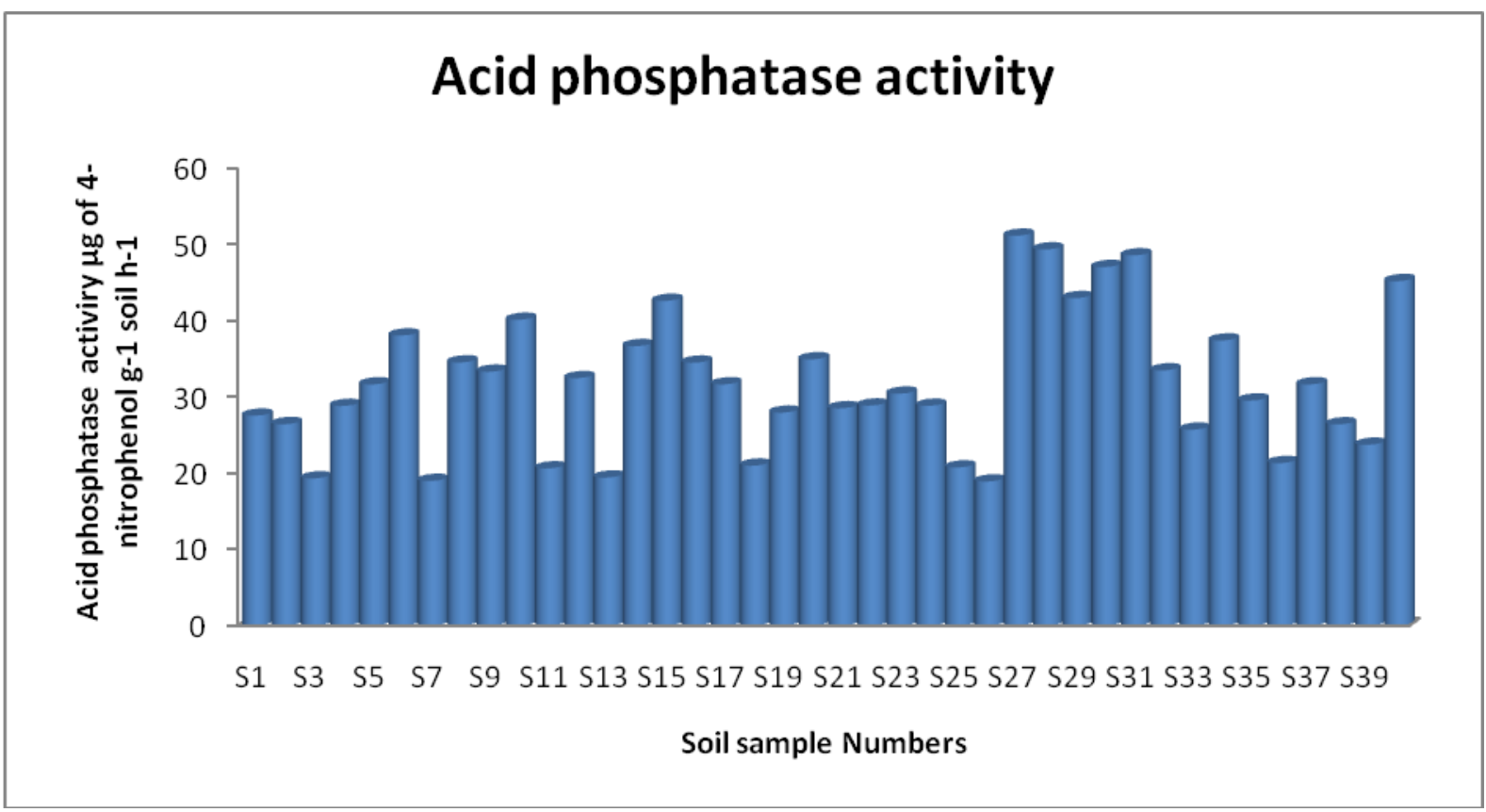

Statistical analysis of various physico chemical properties of soil with soil enzyme acid phosphatase

CORRELATION MATRIX

\begin{tabular}{|c|c|c|c|c|c|c|c|}
\hline & sand & silt & clay & $\mathrm{Ph}$ & $\begin{array}{l}\text { organic } \\
\text { carbon }\end{array}$ & ec & $\begin{array}{l}\text { avail } \\
\text { nitrogen }\end{array}$ \\
\hline sand & 1.00000 & $-0.55848^{* * *}$ & $-0.92708^{* * *}$ & -0.28989 & -0.04715 & -0.30091 & -0.23688 \\
\hline silt & & 1.00000 & 0.20901 & -0.01817 & 0.11858 & 0.21321 & 0.20516 \\
\hline clay & & & 1.00000 & 0.35098 * & -0.01361 & 0.25789 & 0.17024 \\
\hline $\mathrm{Ph}$ & & & & 1.00000 & 0.02773 & -0.06303 & 0.23124 \\
\hline organic carbon & & & & & 1.00000 & -0.16325 & $0.55017^{\text {** }}$ \\
\hline ec & & & & & & 1.00000 & 0.10443 \\
\hline avail nitrogen & & & & & & & 1.00000 \\
\hline
\end{tabular}

$\begin{array}{lrr} & \mathrm{p} 205 & \mathrm{k} 20 \\ \text { sand } & 0.00902 & 0.01964 \\ \text { silt } & -0.11440 & -0.06092 \\ \text { clay } & 0.02842 & 0.01001 \\ \text { Ph } & 0.19901 & 0.06993 \\ \text { organic carbon } & 0.40652^{* *} & 0.02545 \\ \text { ec } & 0.08367 & -0.20490 \\ \text { avail nitrogen } & 0.55392^{* * *} & 0.07504 \\ \text { p205 } & 1.00000 & 0.04311 \\ \text { k20 } & & 1.00000\end{array}$


Yi Variable $=$ acid $\mathrm{p}$

$Y 3=30.9524+0.01849 x$

$Y 3=33.1372-+0.07208 x$

$Y 3=32.5556-+0.01864 x$

$Y 3=31.7436+0.05602 x$

$Y 3=21.1546+19.65897 x$

$Y 3=33.2282-+4.42929 x$

$Y 3=13.3567+0.06352 x$

$Y 3=18.2598+0.37099 x$

$Y 3=31.1187+0.00425 x$ sand

silt

clay

$\mathrm{Ph}$

organic carbon

ec

avail nitrogen

p205

k20 t Value

0.1843

0.2736

0.1577

0.0289

6.6929

0.5135

3.6895

7.5903

0.2716
Probability

0.8547

0.7859

0.8755

0.9771

$0.0000^{* * *}$

0.6106

$0.0007^{\text {*** }}$

$0.0000 * * *$

0.7874
However, there had also been reports of nonsignificant correlation (Sanikidze et al., 1973) and even a negative relationship (Kozlov et al., 1973) between phosphatase activity and organic carbon content of the soil. From the literature, soil phosphatase activity can be related to soil organic matter (Kiss et al., 1974, Nannipieri et al., 1973, Jordan and Kremer 1994, Aon and Colaneri, 2001 and others), total nitrogen (Speir, 1978, Aon and Colaneri, 2001 and others), soil organic phosphorus content (Gavrilova et al., 1973 and others).

Mamytov et al., (1974) found that in certain cultivated soils of Russia, alkaline phosphatase activity was inversely related, whereas, acid and neutral phosphatase activities were directly related to organic phosphorous content. Soil phosphatase activity had been reported to be significantly correlated to total nitrogen also, presumably because it is closely related to organic carbon itself (Harrison, 1983). Chhonkar and Tarafdar, (1984) reported that the phosphatase activity was significantly and positively correlated with organic carbon content, organic phosphorus and bacterial population but it had a negative relationship with a $\mathrm{pH}$ of soil.

Soil phosphatase activity has also been shown to vary with soil depth (Harrison, 1983), season (Harrison and Pearce, 1979), and with the type of plants present (Harrison, 1983).
Soil phosphatase correlated with other chemical and biological properties of the soils. Bonmati et al., (1991) assert that phosphatase activity in soils from experimental plots, after storage at room temperature for 1 year. before being analysed, was correlated with protease, total $\mathrm{N}$ and organic C. Sahrawat (1983) measured the biological activity in crop rotation using microbial biomass and enzyme activity as parameters. Microbial biomass and alkaline phosphatase in barley fields were correlated to $\mathrm{pH}$ values and the organic $\mathrm{C}$ content of the soil. The influence of $\mathrm{pH}$ on the rate of phosphatase activity has also been described by Herbien and Neal, (1990). AcostaMartinez and Tabatabai, (2000) described the correlations between phosphatases activity and $\mathrm{pH}$ as the effect of eight lime application rates. The wide reports in the 1980 s by Chhonkar and Tarafdar, (1984) described positive correlations of phosphatase activity with organic carbon, organic phosphorus and bacterial populations, and a negative relationship with soil pH. Nahas et al., (1994) the activity of acid and alkaline phosphatase correlated with organic matter and total phosphorus content, but not with available phosphorus and organic phosphorus content. The phosphatase producing bacterial population was favoured by the level of available phosphorus.

The results of correlations and linear equations between phosphatase activity and soil characteristics was studies by Sarapatka, 
(2003), Positive correlations were found between enzymatic activity and organic carbon, and with nitrogen, and between acid phosphatase activity and total phosphorus. Negative correlations were with the quality of humus (humic: fulvic acids ratio) and available phosphorus, and between acid phosphatase activity and clay content and $\mathrm{pH}$. Zibilske and Bradford, (2003) have found significant correlation between phosphatase activity, extractable $\mathrm{P}$ and dissolvable organic carbon. Similar findings were also given by Turner et al., (2002). Their study indicated a link between soluble $\mathrm{P}$ in the soil and increased biological and enzyme activity resulting in improvement in soil organic matter content caused by tillage reduction. The results suggest there may be difference in substrate composition that results from conservation tillage and leading to difference in enzyme activity.

The higher correlation of phosphatase activity with organic carbon content could be due to the fact that the organic matter is the seat of microbial population and activity.

\section{References}

Acosta-Martínez, V., Tabatabai MA 2000. Enzyme activities in a limed agricultural soil Biology and Fertility of Soils 31, 85-91.

Aon, M.A., and Colaneri, A.C. 2001. Temporal and special evaluation of enzymatic activities and physicochemical properties in agricultural soil. Applied Soil Ecology. 18: 255 - 270.

Bonmati, M.C., Ceccanti B, Nannipieri, P. 1991. Spatial variability of phosphatase, urease, protease, organic carbon and total nitrogen in soil. Soil Biology and Biochemistry 23:391-396

Bouyoucos, G.J., 1962. Hydrometer method improved for making particle size analyses of soils. Agronomy. Journal. 54:464-465.
Chhonkar, P.K., and Tarafdar, J.C. 1984. Accumulation of phosphatases in soils. Journal of the Indian Society of Soil Science. 32: 266-272.

Eivazi, F., and Tabatabai, M.A. 1977. Phosphatases in soils. Soil Biology and Biochemistry. 9: 167-172.

Gavrilova, A.N., N.A. Shimko and V.F. Savcenko, 1973. Dynamics of organic phosphorus compounds and phosphatase activity in pale yellow sodpodzolic soil. Soviet Soil Science. 3: 320-328.

Gianfreda, L., Rao, A.M., Piotrowska, A., Palumbo, G and Colombo, C. 2005. Soil enzyme activities as affected by anthropogenic alterations: Intensive agricultural practices and organic pollution. Science of the Total Environment. 341: 265-279.

Harrison, A.F., 1983. Relationship between intensity of phophatase activity and physico-chemical properties in woodland soils. Soil Biology and Biochemistry. 15(1): 93-99.

Harrison, A.F., and Pearce, T. 1979. Seasonal variation of Phosphatase activity in woodland soils. Soil Biology and Biochemistry. 11: 405-410.

Herbiena, S.A., and Neala, J.L. 1990. Soil pH and phosphatase activity. Communications in Soil Science and Plant Analysis. 21(5-6): 439 - 456.

Jackson, M.L., 1967. Soil chemical analysis. Prentice Hall of India, New Delhi.

Jackson, M.L., 1973. Soil chemical analysis. Prentice Hall of India Private Limited., New Delhi.

Jordan, D., Kremer R.J., Bergfield W.A., Kim K.Y., Cacnio V.N. (1995): Evaluation of microbial methods as potential indicators of soil quality in historical agriculture fields. Biology and Fertility of Soils, 19: 297-302

Kalyani, K., 2011. Potassium status of cauliflower Brassica Oleracea, Var, 
Botrytis growing soils of Ranga Reddy district in relation to the short term and long term availability. $M S c$ Thesis. Acharya N G Ranga Agricultural University, Hyderabad

Khaziev, F. Kh and Burangulova, M.N. 1965. Activity of enzymes which dephosphorylate organic phosphorus compounds of soil. In R.G. Burns (eds.) - Soil Enzymes, Academic Press Inc, New York.

Kiss, S., Dragan-Bularda, M and Radulescu, D. 1975. Biological significance of enzymes accumulated in soil. Advances in Agronomy. 27: 25-87.

Kozlov, K.A., Kislitsina, V and Markova, Yu. 1973. Enzymic activity and humus content in Eastern Siberian soils. In R.G. Burns (eds.) - Soil Enzymes, Academic Press Inc, New York.

Mamytov, A.M., Vovonov, S.I and Tynaevzh, M. 1974. Composition of phosphorus compounds and phosphatase activity of soils of the territory brought under cultivation in the Issyk-Kul Basin of Kirozia. Dokl Vses Akad Sel 'skokhoz Nauk. 3: 5-7.

Nahas, E., Centurion, J.F. and Assis, L.C. 1994. Efeito das caracteristicas quimicas dos solos sobre os microorganismos solubilizatores de fosfato e produtores de fosfatases. Revista Brasileira de Ciencia de Solo, 18:1: 49-53

Nannipieri, P., Cerevelli, S and Perna, A. 1973. Enzyme activities in some Italian Soils. In R.G. Burns (eds.) - Soil Enzymes, Academic Press Inc, New York.

Olsen, S.R., Cole, C.V., Watanabe, F.S and Dean, L.A. 1954. Estimation of available phosphorus in soils by extraction with sodium bicarbonate. Circulation from USDA, 939.

Pavani, G. L- glutaminase activity in soils assay, distribution, kinetics and the effect of crop cover on its activity 2015 $M$ Sc Thesis. Professor Jayashankar Telangan State Agricultural University, Hyderabad

Sahrawat, K.L., 1983. Relationship between soil urease activity and other properties of some tropical wetland rice soils. Fertilizer Research. 4(2): 145-150.

Sanikidze, G.S., Gogorikidze, N.I and Shoniya, N.K. 1973. Enzymatic activity of basic soil types of the subtropical zones of the western Georgian. Chemistry Abstracts 114397, 1974.

Sanikidze, G.S., Gogorikidze, N.I and Shoniya, N.K. 1973. Enzymatic activity of basic soil types of the subtropical zones of the western Georgian. Chemistry Abstracts 114397, 1974

Singh, D., Chhonkar, P.K. and Pandey, R.N. 1980. Soil plant water analysis in: $A$ Methods Manual. Indian Agricultural Research Institute, New Delhi.

Speir, T.W., 1977. Studies on a climosequence of soils in tussock grasslands II Urease phosphatase and sulphatase activities of top soils and their relationships with other properties including plant available sulphur. In R.G. Burns (eds.) - Soil Enzymes, Academic Press Inc, New York.

Speir, T.W., and Ross, D.J. 1978. Soil phosphatase and sulphatase. In R.G. Burns (eds.) - Soil Enzymes, Academic Press Inc, New York.

Sriramachandrasekharan, M.V., Ramanathan, G and Ravichandran, M. 1997. Effect of different organic manures on enzyme activities in flooded rice soil. Oryza. 34: 39-42.

Subbaiah, B.V., and Asija, G.L. 1956. A rapid procedure for the determination of available nitrogen in soils. Current Science. 25: 259-260.

Tabatabai, M.A., 1994. Microbiological and biochemical properties. In R.W. Weaver, J.S. Angle and P.S. Bottomley 
(eds.) - Methods of Soil Analysis, Part 2, Soil Enzymes, Soil Science Society, Society of America Madison. 775 - 833

Tabatabai, M.A., and Bremner, J.M. 1969. Use of P-nitrophenyl phosphate for assay of soil phosphatase activity. Soil Biology and Biochemistry. 1: 301-307.

Turner, B.L., Baxter, R and Whitton, B.A. 2002. Seasonal phosphatase activity in three characteristics soils of English uplands polluted by long term atmospheric nitrogen deposition. Environmental Pollution. 120: 313 317.

Vandana, J.L., 2012. Urease and phosphomonoesterase activities in soil their distribution, kinetics and influence of management practices on their activities. Ph D Thesis. Acharya N G Ranga Agricultural University, Hyderabad

Walakley, A., and Black, C.A. 1934. Estimation of organic carbon by chromic acid titration method. Soil Science. 37: 29-38.

Zahir, Z.A., M.A.R. Malik and M. Arshad, 2001. Soil enzymes research: a review. Online Journal of Biological. Science, 1: 299-307

Zibilske, L.M., and Bradford, J.M. 2003. Tillage effects on phosphorous mineralization and microbial activity. Soil Science. 168(10): 677-685.

\section{How to cite this article:}

Aruna Kumari, J., P.C.Rao, G. Padmaja, Madhavi, M. 2017. Effect of Physico-Chemical Properties on Soil Enzyme Acid Phosphatase Activity of Some Soils in Vegetable Growing Soils of Ranga Reddy District of Telangana State. Int.J.Curr.Microbiol.App.Sci. 6(10): 34963503. doi: https://doi.org/10.20546/ijcmas.2017.610.412 